\title{
$\alpha$-glucosidase and $\alpha$-amylase Inhibitory Properties of A1 and A2 Cow Milk Casein Hydrolysate
}

\author{
Lalita Garg ${ }^{*}$, Geeta Chauhan ${ }^{1}$ and Kamal Kumar ${ }^{2}$
}

${ }^{1}$ Division of Livestock Products Technology, ${ }^{2}$ Division of Extension Education, ICAR-Indian Veterinary Research Institute, Izatnagar, Bareilly, U.P., India

*Corresponding author

Keywords

A1/A2 cow milk, Enzymatic hydrolysis, A1/A2 casein hydrolysate, $\alpha$-glucosidase inhibition, $\alpha$ amylase inhibition

Article Info

Accepted:

17 January 2021

Available Online: 10 February 2021
This research intended to examine the in vitro health-promoting benefits (namely $\alpha$-glucosidase, and $\alpha$-amylase inhibition) of A1 and A2 cow milk casein digested with trypsin. Both A1 and A2 casein hydrolysates manifested $\alpha$-glucosidase, and $\alpha$-amylase inhibition, whereas improved activity was recorded with progress in time and degree of hydrolysis. The results indicated that hyperglycaemia was partially control by $\alpha$ glucosidase, and $\alpha$-amylase inhibitory properties of casein-derived peptides. It can use as functional food ingredients in the diet of patients with type 2 diabetes.

\section{Introduction}

Cow milk serves as a foremost source of nutrition for neonates. Milk proteins release functional bioactive peptides upon enzymatic hydrolysis, using microbial and plant-derived enzymes (Korhonen and Pihlanto, 2003; Fuglsang et al., 2003). Casein ( $\alpha$ s1, $\alpha$ s2, $\beta$, and $\kappa$-casein) and whey proteins $(\alpha-$ lactalbumin, $\beta$-lactoglobulin, and lactoferrin) release bioactive peptides (Nielsen et al., 2017). Casein is considered a high biological value protein due to a high level of the essential amino acid and protein digestibility corrected amino acid score (Boye et al., 2012; Schaafsma, 2000). There exist two variants of $\beta$-casein, A1, and A2, based on the amino acid position. At $67^{\text {th }}$ position, A1 casein has histidine whereas, A2 consists of proline.

Diabetes is designated as a lack of insulin secretion and insulin resistance (DeFronzo et al., 2009), and type 2 diabetes mellitus (DM) is the most prevalent form of diabetes. It is responsible for oxidative stress, lipid oxidation, high clotting tendency, and the 
inflammatory process (Brand-Miller et al., 2007). Type 2 DM, embroiled by several factors, such as insulin resistance, hyperinsulinemia, impaired insulin secretion, reduced insulin-mediated glucose uptake, and utilization (Tiwari et al., 2002). A swift increase of postprandial glucose level in type $2 \mathrm{DM}$ is due to the hydrolysis of starch by pancreatic $\alpha$-amylase and glucose absorption by $\alpha$-glucosidase. An efficient approach to control type 2 diabetes is the inhibition of pancreatic $\alpha$-amylase and intestinal $\alpha$ glucosidase. Although there are numerous synthetic pancreatic $\alpha$-amylase and intestinal $\alpha$-glucosidase inhibitors available commercially for therapeutic use, their effectiveness is limited by harmful sideeffects such as abdominal distension, and flatulence. Casein-derived bioactive peptides possess the potential to inhibit pancreatic $\alpha$ amylase and $\alpha$-glucosidase (Jan et al., 2016). $\alpha$-amylase is an enzyme acting on the $\alpha-1,4-$ glycosidic bond of starch and glycogen to yield dextrin, maltose, and glucose. It is an endo-acting enzyme since it attacks inner glycosidic linkage to break down the starch into glucose before absorption. $\alpha$-amylase inhibition would detain carbohydrate digestion resulting in a decreased rate of glucose absorption (Rabasa-Lhoret et al., 2004). Prolonged exposure to the high glucose level in type $2 \mathrm{DM}$ patients causes the production of free radicals, particularly reactive oxygen species, due to the negotiated antioxidative mechanism of the body.

Therefore, this research designed to investigate the in vitro health-promoting benefits namely $\alpha$-glucosidase, and $\alpha$-amylase inhibition of A1 and A2 cow milk casein digested with trypsin at different casein concentrations, and at a various time of hydrolysis and also the comparison between the casein variant derived from the A1 and A2 cow milk.

\section{Materials and Methods}

\section{Milk}

For casein hydrolysate preparation, milk was collected from the Cattle and Buffalo Farm, ICAR-Indian Veterinary Research Institute, Izatnagar, Bareilly, where cow's herd genotyped as A1A1 and A2A2 by the Division of Animal Genetics and Breeding (AGB Division) of the institute.

\section{Enzymatic hydrolysis of A1 and A2 casein}

Cow milk casein powder was prepared, according to the method narrated by Salami $e t$ al., (2011) in the Division of Livestock Products Technology, ICAR-IVRI, Izatnagar. Cow milk whole casein $(1 \%, 3 \%$, and 5\% w/v) solution, was prepared by reconstituting the casein in distilled water. The casein solution was heated in a boiling water bath for $5 \mathrm{~min}$ to destroy the microorganisms, if present, which might produce proteolytic enzymes throughout the hydrolysis process. Besides this, it denatures the inherent enzymes in milk, if present, and to denature, the proteins which enhance its sensitivity to proteolytic enzymes. Enzyme/substrate ratio of 1:100 (w/w) was kept constant for trypsin (Thakur et al., 2020). The optimum temperature and $\mathrm{pH}$ for enzymatic hydrolysis were $37{ }^{\circ} \mathrm{C}$ and 8.0 (Otte et al., 2007). The hydrolysis did accomplish by incubating the samples at $37{ }^{\circ} \mathrm{C}$ for trypsin in a stirred water bath. Representative samples extracted after a definite time interval i.e. $2 \mathrm{~h}, 4 \mathrm{~h}$, and $6 \mathrm{~h}$ of incubation. Each hydrolyzed samples were instantly warmed to $85{ }^{\circ} \mathrm{C}$ for $15 \mathrm{~min}$ in a water bath to inactivate the enzymes left in the hydrolysates. Then the samples were cooled and centrifuged in the refrigerated centrifuge (Hermle, High-Speed Universal Refrigerated Centrifuge) at 10,000 rpm for 20 min, and the supernatant was collected and stored at $-20{ }^{\circ} \mathrm{C}$ until further use. 
Determination of in vitro antidiabetic activity of casein hydrolysates

$\alpha$-glucosidase inhibition assay

$\alpha$-glucosidase inhibition assay was carried out by following Apostolidis et al.,(2007) protocol. The $\alpha$-glucosidase inhibitory activity could be measured in vitro by determinating the p-nitrophenol (PNP) after hydrolysis of p-Nitrophenyl- $\alpha-\mathrm{D}$ glucopyranoside (PNPG) by the $\alpha$-glucosidase enzyme. The $\alpha$-glucosidase assay was exhibited by adding $50 \mu$ of the sample with $100 \mu \mathrm{l}$ of 0.1 Mphosphate buffer $(\mathrm{pH}$ 6.9) containing $\alpha$-glucosidase solution $(1.0 \mathrm{U} / \mathrm{ml})$ from Saccharomyces cerevisiae. After preincubation at $25^{\circ} \mathrm{C}$ for $10 \mathrm{~min}, 50 \mu \mathrm{l}$ of $5 \mathrm{mM}$ PNPG solution in $0.1 \mathrm{M}$ phosphate buffer $(\mathrm{pH}$ 6.9) was added as substrate. The mixture was further incubated at $25{ }^{\circ} \mathrm{C}$ for $5 \mathrm{~min}$. The reaction was stopped by the addition of $1 \mathrm{ml}$ of $0.1 \quad \mathrm{M} \quad \mathrm{Na}_{2} \mathrm{CO}_{3}$. Before and after incubation, absorbance (A) readings of samples were recorded at $405 \mathrm{~nm}$ by a Microplate reader (Thermo Fisher Scientific) and compared to a control, which had $50 \mu$ of buffer solution in place of the sample. The $\alpha$ glucosidase inhibitory activity was expressed as $\%$ inhibition and calculated as follows:

$\% \alpha$-glucosidase inhibition:

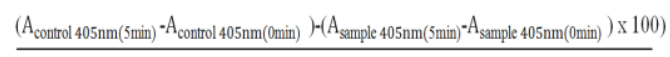

$$
\begin{aligned}
& \left(\mathrm{A}_{\text {control }} 405 \mathrm{~nm}(5 \min )-\mathrm{A}_{\text {control } 405 \mathrm{~nm}(0 \mathrm{~min})}\right)
\end{aligned}
$$

\section{$\alpha$-amylase inhibition assay}

The $\alpha$-amylase inhibition assay was performed according to the method described by Kim et al., (2004) and Apostolidis et al., (2007) with some modifications. $100 \mu 10.02$ $\mathrm{M}$ sodium phosphate buffer (pH 6.9 with $0.006 \mathrm{M} \mathrm{NaCl})$ containing $\alpha$-amylase solution $(0.5 \mathrm{mg} / \mathrm{ml})$ was premixed with $100 \mu \mathrm{l}$ of hydrolysate samples. After pre-incubation at $37{ }^{\circ} \mathrm{C}$ for $7 \mathrm{~min}, 250 \mu \mathrm{l}$ of $1 \%$ starch solution in $0.02 \mathrm{M}$ sodium phosphate buffer ( $\mathrm{pH} 6.9$ with $0.006 \mathrm{M} \mathrm{NaCl}$ ) was added as a substrate in phosphate buffer $(\mathrm{pH}$ 6.9). The reaction was performed at $37{ }^{\circ} \mathrm{C}$ for $7 \mathrm{~min}$ and terminated by the addition of $200 \mu \mathrm{l}$ of dinitrosalicylic acid (DNSA) reagent $(96 \mathrm{mM}$ DNSA and $5.3 \mathrm{M}$ sodium potassium tartrate in $2.0 \mathrm{M} \mathrm{NaOH}$ ). The reaction mixture was heated for $15 \mathrm{~min}$ at $100{ }^{\circ} \mathrm{C}$ and diluted with 2 $\mathrm{ml}$ of distilled water. $\alpha$-amylase inhibitory activity was determined by measuring absorbance at $540 \mathrm{~nm}$.

$\% \alpha$-amylase inhibition $=$

$A_{540}^{\text {control }}-A_{540}^{\text {sample }} / A_{540}^{\text {control }} \times 100$

\section{Statistical analysis}

Data are presented as mean \pm standard error (SE) of nine independent experiments. Data were analyzed using the SPSS package (SPSS 20, Version 20, IBM, USA). The difference between the mean was compared using a $\mathrm{t}$ test. Further, Significant differences were determined using Tukey tests $(\mathrm{p}<0.05)$. Data obtained from the experiments were pooled. Firstly A1 and A2 samples were compared within the group based on the time of hydrolysis and then based on casein concentration furthermore a comparison was made between $\mathrm{A} 1$ and $\mathrm{A} 2$ at the same time period of hydrolysis.

\section{Results and Discussion}

\section{Determination of in vitro antidiabetic} activity of casein hydrolysates

\section{a-glucosidase inhibition}

$\alpha$-glucosidase inhibitory activity for $1 \%, 3 \%$, and $5 \%$ casein hydrolysates, ranged from $8.80-17.46 \%, \quad 11.17-23.28 \%$, and 15.34$29.80 \%$, respectively (Fig. 1). The 
comparison of $\alpha$-glucosidase inhibitory activity within the groups unveiled a significant $(p<0.05)$ increase in activity of A1 and A2 casein hydrolysates at $2 \mathrm{~h}, 4 \mathrm{~h}$, and 6 $\mathrm{h}$ of hydrolysis in comparison with whole casein (Table 1).

The differentiation among different casein concentrations showed a significant $(\mathrm{p}<0.05)$ increase of $\alpha$-glucosidase inhibition in both $\mathrm{A} 1$ and A2 casein hydrolysates at $0 \mathrm{~h}, 2 \mathrm{~h}, 4$ $\mathrm{h}$, and $6 \mathrm{~h}$ of hydrolysis beside the highest activity recorded in 5\% followed by $3 \%$ and $1 \%$ (Fig. 1). $\alpha$-glucosidase inhibition was directly proportional to the hydrolysis time and casein concentration (Table 1).

In the case of $1 \%$ casein, no significant difference $(p>0.05)$ was observed between A1 and A2 casein hydrolysates, irrespective of the time of hydrolysis. At 3\% and 5\% casein level, A2 showed significantly $(\mathrm{p}<0.05)$ higher $\alpha$-glucosidase inhibitory activity than A1 casein hydrolysate at $4 \mathrm{~h}$ and6 $\mathrm{h}$ of hydrolysis (Table 1).
Lacroix et al., (2013) stated that $\beta$ lactoglobulin and whey protein hydrolyzed with pepsin showed $33 \%$ and $36 \%$ of $\alpha$ glucosidase inhibition, respectively, which was higher than the present findings due to utilization of whey protein. Yogurt, chicken essence, and fish sauce showed inhibitory potential against yeast $\alpha$-glucosidase (Oki et al., 1999). Further, researchers have reported higher $\alpha$-glucosidase inhibition in the milk products incorporated with various plant extracts. Allium sativum enriched cow (15\%) and camel (12\%) milk yogurt showed higher $\alpha$-glucosidase inhibition as compared to plain yogurt (Shoriet al., 2011). Apostolidis et al., (2007) recorded 74\% $\alpha$-glucosidase inhibitory activity in cranberry enriched cheese. Phytochemicals had a positive impact on health and could be explored further (Bravo, 1998). Aloe gel enriched curd manifested more prominent $\alpha$-glucosidase inhibition than plain curd (Ramachandran et al., 2014). Ayyash et al., (2018) reported Lactobacillus plantarum fermented bovine milk had higher $\alpha$-glucosidase inhibitory potential than camel milk.

Table.1 $\alpha$-glucosidase inhibitory potential of A1 and A2 casein hydrolysates with different casein concentrations at various time periods of hydrolysis $($ Mean \pm SE)

\begin{tabular}{|c|c|c|c|c|c|c|c|c|}
\hline $\begin{array}{l}\alpha \text {-glucosic } \\
\text { hydrolysi }\end{array}$ & $\begin{array}{l}\text { e inhibitory } \\
\text { Mean } \pm \text { SE) }\end{array}$ & ntial of $A$ & A2 caseiı & olysate & h different & sein conc & tion & ime periods \\
\hline Casein & & & & $\alpha$-glucosidas & inhibition (\% & & & \\
\hline concentr & & & & Time of & hydrolysis & & & \\
\hline & & & 2 & & 4 & & & \\
\hline & $\begin{array}{l}\text { A1 casein } \\
\text { hydrolysate }\end{array}$ & $\begin{array}{c}\text { A2 casein } \\
\text { hydrolysate }\end{array}$ & $\begin{array}{c}\text { A1 casein } \\
\text { hydrolysate }\end{array}$ & $\begin{array}{c}\text { A2 casein } \\
\text { hydrolysate }\end{array}$ & $\begin{array}{c}\text { A1 casein } \\
\text { hydrolysate }\end{array}$ & $\begin{array}{c}\text { A2 casein } \\
\text { hydrolysate }\end{array}$ & $\begin{array}{c}\text { A1 casein } \\
\text { hydrolysate }\end{array}$ & $\begin{array}{l}\text { A2 casein } \\
\text { hydrolysate }\end{array}$ \\
\hline $\begin{array}{l}1 \% \\
\text { casein }\end{array}$ & $8.80 \pm 0.37^{3 d}$ & $9.03 \pm 0.38^{3 \mathrm{D}}$ & $12.52 \pm 0.35^{3 c}$ & $13.48 \pm 0.40$ & $\begin{array}{c}15.14 \pm 0.2 \\
7^{3 \mathrm{~b}}\end{array}$ & $\underset{3 \mathrm{~B}}{15.94 \pm 0.26}$ & $17.10 \pm 0.28^{3 a}$ & $17.46 \pm 0.33^{3 \mathrm{~A}}$ \\
\hline $\begin{array}{l}3 \% \\
\text { casein }\end{array}$ & $11.17 \pm 0.30^{2 \mathrm{~d}}$ & $11.51 \pm 0.24$ & $18.37 \pm 0.27^{2 \mathrm{c}}$ & $18.43 \pm 0.26$ & $\begin{array}{c}20.32 \pm 0.3 \\
1^{2 b}\end{array}$ & $\begin{array}{c}21.46 \pm 0.30 \\
* 2 \mathrm{~B}\end{array}$ & $22.14 \pm 0.32^{2 a}$ & $23.28 \pm 0.37 *^{2 \mathrm{~A}}$ \\
\hline $\begin{array}{l}5 \% \\
\text { casein }\end{array}$ & $15.34 \pm 0.33^{1 d}$ & $\underset{1 \mathrm{D}}{15.69 \pm 0.29}$ & $24.10 \pm 0.31^{\mathrm{lc}}$ & $\underset{1 \mathrm{C}}{24.73 \pm 0.35}$ & $\begin{array}{c}25.79 \pm 0.2 \\
8^{1 \mathrm{~b}}\end{array}$ & $\begin{array}{c}26.87 \pm 0.27 \\
* 1 \mathrm{~B}\end{array}$ & $28.56 \pm 0.28^{1 a}$ & $29.80 \pm 0.29 * 1 \mathrm{~A}$ \\
\hline
\end{tabular}


Table. $2 \alpha$-amylase inhibitory potential of A1 and A2 casein hydrolysates with different casein concentrations at various time periods of hydrolysis (Mean $\pm \mathrm{SE}$ )

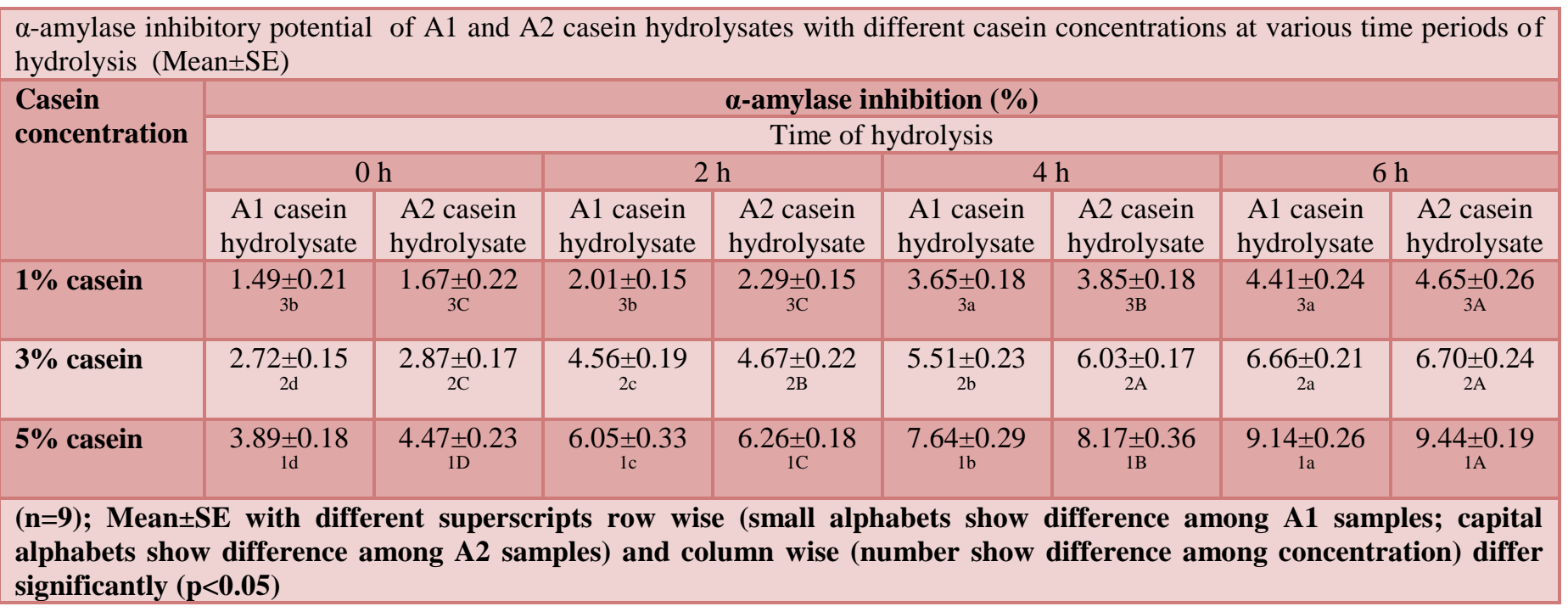

Fig.1 $\alpha$-glucosidase inhibition of A1 and A2 casein hydrolysates with different casein concentrations at various time periods of hydrolysis

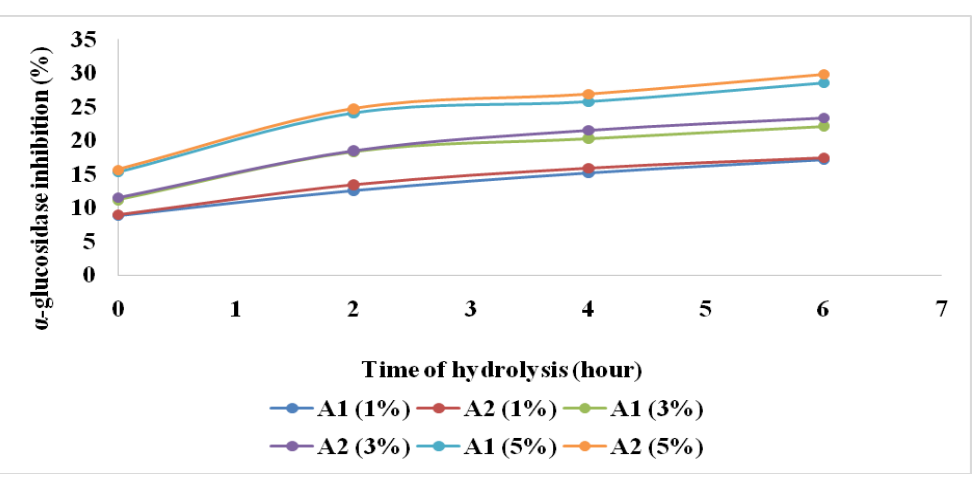

Fig.2 $\alpha$-amylase inhibition of A1 and A2 casein hydrolysates with different casein concentrations at various time periods of hydrolysis

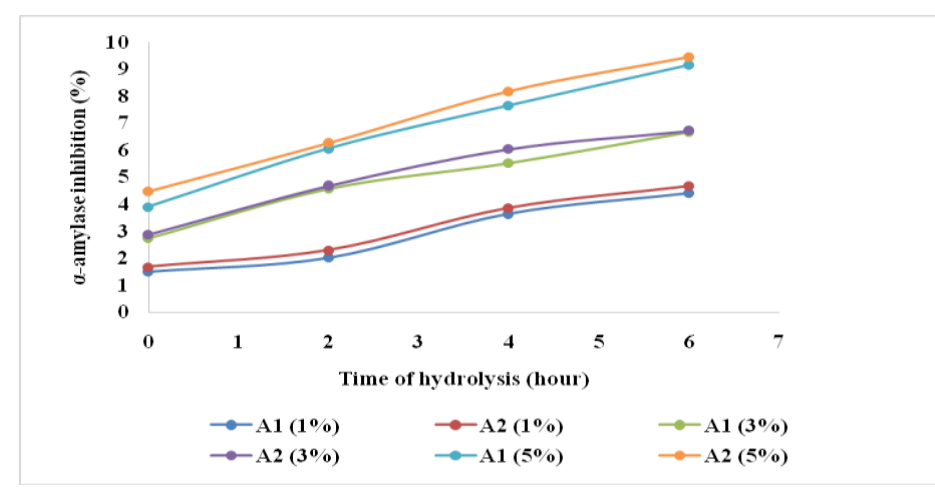




\section{Pancreatic $\alpha$-amylase inhibition}

The comparison within the groups revealed that, at $1 \%$ casein, $\alpha$-amylase inhibiting activity of A1 casein hydrolysates obtained at $4 \mathrm{~h}$ of hydrolysis increased significantly $(\mathrm{p}<0.05)$ from $0 \mathrm{~h}$ and $2 \mathrm{~h}$ and hereafter, the increase were not significant $(\mathrm{p}>0.05)$. However, A2 casein hydrolysate showed a significant $(\mathrm{p}<0.05)$ increase in activity at $4 \mathrm{~h}$ and $6 \mathrm{~h}$. At $3 \%$ casein, a significant $(\mathrm{p}<0.05)$ increase was observed at $2 \mathrm{~h}, 4 \mathrm{~h}$, and $6 \mathrm{~h}$ in A1 casein hydrolysates. However, in the case of A2 casein hydrolysate, a significant $(\mathrm{p}<0.05)$ increase was observed at $2 \mathrm{~h}$ and $4 \mathrm{~h}$ of hydrolysis, afterward the increase was nonsignificant ( $>0.05)$. In the case of $5 \%$ casein, both $\mathrm{A} 1$ and $\mathrm{A} 2$ casein hydrolysates showed a significant $(\mathrm{p}<0.05)$ increase in activity at $2 \mathrm{~h}$, $4 \mathrm{~h}$, and $6 \mathrm{~h}$ of hydrolysis (Table 2). $\alpha$ amylase inhibiting activity of casein hydrolysate varied from $1.49-4.65 \%, 2.72-$ $6.70 \%$, and $3.89-9.44 \%$ for $1 \%, 3 \%$, and $5 \%$ casein respectively (Fig. 2)

The distinction among different concentrations of casein at the same time interval showed a significant $(\mathrm{p}<0.05)$ increase in $\alpha$-amylase inhibition with an increase in casein concentration in both the variants of casein hydrolysates (Table 2).

Additionally, no significant difference ( $p>0.05)$ was observed between A1 and A2 casein hydrolysates at $0 \mathrm{~h}, 2 \mathrm{~h}, 4 \mathrm{~h}$, and $6 \mathrm{~h}$ of hydrolysis in all casein concentrations (Table 2).

To our knowledge, no records available on the in vitro antidiabetic activity of $\mathrm{A} 1$ and $\mathrm{A} 2$ casein hydrolysate against $\alpha$-amylase. Jan et al., (2016) reported $44 \%, 43 \%$, and $41 \%$ of $\alpha$ amylase inhibition in sheep raw milk casein hydrolyzed with trypsin, chymotrypsin, and pepsin, respectively, which was higher than the present finding due to utilization of different species casein. Cow and buffalo milk whey fermented with Lactobacillus lactis, Lactobacillus delbeurkii showed $39.18 \%, 46.59 \%$, and $25.09 \%, 32.29 \% \alpha-$ amylase inhibitory potential, respectively (Vankudre et al., 2015), which was higher than the present result due to fermentation of whey. Ayyash et al., (2017) reported $>34 \% \alpha$ amylase inhibition in both bovine and camel milk fermented with different strains of Lactobacillus sp. $\quad \alpha$-amylase $\quad$ inhibitory potential of fermented products could be attributed to the release of bioactive peptides as a consequence of proteolytic enzyme generated by probiotic strains (Da Cruz et al., 2009). Various milk products enriched with numerous plant extracts showed higher $\alpha$ amylase inhibition, as mentioned. Ramachandran et al., (2014) described a dose-dependent increase in $\alpha$-amylase inhibition. Sudha et al., (2011) stated that cold water extract and cyclohexane extract of Aloe vera exhibited inhibitory potential against porcine pancreatic $\alpha$-amylase. Allium sativum enriched cow and camel milk yogurts showed $38 \%$ and $57 \%$ a-amylase inhibitory activity than plain cow and camel milk yogurt i.e. $26 \%$ and $33 \%$, respectively (Shoriet al., 2011), higher than the present study due to the inclusion of Allium sativum in yogurt and fermentation of milk. S-allyl cysteine sulfoxide (alliin) and sulfur-containing amino acid in Allium sativum manifested $\alpha$-amylase inhibitory activity (Augustiet al., 1996). Apostolidis et al., (2007) reported 52-100\% $\alpha$-amylase inhibition in cranberry enriched cheese with an increase in dosage from $125 \mu$ l$500 \mu 1$. $\alpha$-amylase inhibitory activity of Roquefort cheese assigned to specific phenolic or secondary metabolite from Penicillium sp. (Apostolidis et al., 2007).

In Conclusion, the prevention is as important as the treatment of disease. With the burgeoning interest in nutraceuticals domains, 
more and more research is targeted to find the new bioactive compound in different food products. Milk is deemed to be a significant source of bioactive peptides. Additionally, it has a positive impact on the promotion of health and prevention of disease. To mimic digestion $\mathrm{A} 1$ and $\mathrm{A} 2$ casein was hydrolyzed with trypsin to release functional peptides. Both A1 and A2 casein hydrolysate manifested significantly $(p<0.05)$ higher $\alpha$ glucosidase, and $\alpha$-amylase inhibitory activity than whole casein. At some points of hydrolysis A2 showed significantly $(\mathrm{p}<0.05)$ higher activity than $\mathrm{A} 1$. The results indicated that hyperglycemia were partially control $\alpha$ glucosidase, and $\alpha$-amylase inhibitory properties of casein-derived peptides. Moreover, being derived from a natural protein source, it may have fewer side effects. However, more studies are required to isolate peptides and to use these peptides as medicine.

\section{Acknowledgments}

The authors are grateful to the Director of ICAR-Indian Veterinary Research Institute (IVRI), Izatnagar, Bareilly, for providing funding and laboratory facilities to carry out this piece of work.

\section{Conflicts of interest}

There are none potential conflicts between authors and others that bias ourwork.

Abbreviation: Diabetes mellitus (DM), pnitrophenol (PNP), p-Nitrophenyl- $\alpha$-Dglucopyranoside (PNPG), Dinitrosalicylic acid (DNSA), h (hour), min (minute).

\section{References}

Apostolidis, E., Kwon, Y. I., and Shetty, K. (2007). Inhibitory potential of herb, fruit, and fungal-enriched cheese against key enzymes linked to type 2 diabetes and hypertension. Innovative Food Science and Emerging Technologies, 8(1), 46-54.

Augusti, K. T., and Sheela, C. G. (1996). Antiperoxide effect of S-allyl cysteine sulfoxide, an insulin secretagogue, in diabetic rats. Experientia, 52(2), 115-119.

Ayyash, M., Al-Nuaimi, A. K., Al-Mahadin, S., and Liu, S. Q. (2018). In vitro investigation of anticancer and ACE-inhibiting activity, $\alpha$-amylase and $\alpha$-glucosidase inhibition, and antioxidant activity of camel milk fermented with camel milk probiotic: A comparative study with fermented bovine milk. Food chemistry, 239, 588-597.

Boye, J., Wijesinha-Bettoni, R., and Burlingame, B. (2012). Protein quality evaluation twenty years after the introduction of the protein digestibility corrected amino acid score method. British Journal of Nutrition, 108(S2), S183-S211.

Brand-Miller, J. C., Fatima, K., Middlemiss, C., Bare, M., Liu, V., Atkinson, F., and Petocz, P. (2007). Effect of alcoholic beverages on postprandial glycemia and insulinemia in lean, young, healthy adults. The American journal of clinical nutrition, 85(6), 15451551.

Bravo, L. (1998). Polyphenols: chemistry, dietary sources, metabolism, and nutritional significance. Nutrition reviews, 56(11), 317-333.

Da Cruz, A. G., Buriti, F. C. A., de Souza, C. H. B., Faria, J. A. F., and Saad, S. M. I. (2009). Probiotic cheese: health benefits, technological and stability aspects. Trends in Food Science and Technology, 20(8), 344-354.

DeFronzo, R. A., and Tripathy, D. (2009). Skeletal muscle insulin resistance is the primary defects in type 2 diabetes. Diabetes care, 32(suppl 2), S157-S163.

Fuglsang, A., Rattray, F. P., Nilsson, D., and Nyborg, N. C. (2003). Lactic acid bacteria: inhibition of angiotensin converting enzyme in vitro and in vivo. Antonie van eeuwenhoek, 83(1), 27-34.

Jan, F., Kumar, S., and Jha, R. (2016). Effect of boiling on the antidiabetic property of enzyme treated sheep milk casein. Veterinary world, 9(10), 1152.

Kim, Y. M., Wang, M. H., and Rhee, H. I. (2004). 
A novel $\alpha$-glucosidase inhibitor from pine bark. Carbohydrate research, 339(3), 715717.

Korhonen, H. J., and Pihlanto, A. (2003). Bioactive peptides: Novel applications for milk proteins. Biotechnology Food Science Policy. 1: 133-144

Lacroix, I. M., and Li-Chan, E. C. (2013). Inhibition of dipeptidyl peptidase (DPP)-IV and $\alpha$-glucosidase activities by pepsintreated whey proteins. Journal of agricultural and food chemistry, 61(31), 7500-7506.

Nielsen, S. D., Beverly, R. L., Qu, Y., and Dallas, D. C. (2017). Milk bioactive peptide database: A comprehensive database of milk protein-derived bioactive peptides and novel visualization. Food Chemistry, 232, 673-682.

Oki, T., Matsui, T., and Osajima, Y. (1999). Inhibitory effect of $\alpha$-glucosidase inhibitors varies according to its origin. Journal of agricultural and food chemistry, 47(2), 550-553.

Otte, J., Shalaby, S. M., Zakora, M., and Nielsen, M. S. (2007). Fractionation and identification of ACE-inhibitory peptides from $\alpha$-lactalbumin and $\beta$-casein produced by thermolysin-catalysed hydrolysis. International Dairy Journal, 17(12), 1460-1472.

Rabasa-Lhoret, R., and Chiasson, J. L. (2004). Alpha-glucosidase inhibitors. W: De Fronzo RA, Ferrannini E., Keen H., Zimmet P.(red.) International textbook of diabetes mellitus. Wyd. 3.

Ramachandran, P., and Srividya, N. (2014). In vitro antidiabetic activity and in vivo post prandial glycemic response of aloe gel enriched curd. International Journal of
Food and Nutritional Sciences, 3(1), 38.

Salami, M., Moosavi-Movahedi, A. A., MoosaviMovahedi, F., Ehsani, M. R., Yousefi, R., Farhadi, M. and Haertlé, T. (2011). Biological activity of camel milk casein following enzymatic digestion. Journal of dairy research, $78(4), 471$.

Schaafsma, G. (2000). The protein digestibilitycorrected amino acid score. The Journal of nutrition, 130(7), 1865S-1867S.

Shori, A. B., and Baba, A. S. (2014). Comparative antioxidant activity, proteolysis and in vitro $\alpha$-amylase and $\alpha$-glucosidase inhibition of Allium sativum-yogurts made from cow and camel milk. Journal of Saudi Chemical Society, 18(5), 456-463.

Sudha, P., Zinjarde, S. S., Bhargava, S. Y., and Kumar, A. R. (2011). Potent $\alpha$-amylase inhibitory activity of Indian Ayurvedic medicinal plants. BMC complementary and alternative medicine, 11(1), 5 .

Thakur, N., Chauhan, G., Mishra, B. P., Mendiratta, S. K., Pattanaik, A. K., Singh, T. U.,. .. and Garg, L. (2020). Comparative evaluation of feeding effects of A1 and A2 cow milk derived casein hydrolysates in diabetic model of rats. Journal of Functional Foods, 75, 104272.

Tiwari, A. K., and Rao, J. M. (2002). Diabetes mellitus and multiple therapeutic approaches of phytochemicals: Present status and future prospects. Current science, 30-38.

Vankudre, M., Balpande, A., and Athale, M. (2015). Comparative analysis of $\alpha$-amylase inhibition and antioxidant activity of whey from cow and buffalo milk fermented with lactobacillus species. Biosci Biotech Res Comm, 8, 25-28.

\section{How to cite this article:}

Lalita Garg, Geeta Chauhan and Kamal Kumar 2021. $\alpha$-glucosidase and $\alpha$-amylase Inhibitory Properties of A1 and A2 Cow Milk Casein Hydrolysate. Int.J.Curr.Microbiol.App.Sci. 10(02): 2210-2217. doi: https://doi.org/10.20546/ijcmas.2021.1002.263 